\title{
ADVANCES TO THE STUDY OF INTERNATIONAL PUBLIC ADMINISTRATION
}

Jarle Trondal

ABSTRACT As an area of research, specifying crucial conditions under which international public administration (IPA) may enjoy independence from member-state governments has become an increasingly vibrant research area. This special issue responds to three yet unresolved research tasks: (i) Systematically comparing IPAs by offering large- $\mathrm{N}$ data across cases; (ii) Taking organization seriously by identifying how the organisational architectures of IPAs affect decision-making processes and subsequently the pursuit of public policy making; (iii) Examining the varied consequences of the autonomization of IPAs, notably for member-state public sector governance and for the integration of transnational regulatory regimes.

KEY WORDS Autonomy, international public administration, organization structure, temporal sorting, socialization

International bureaucracies constitute a distinct and increasingly important feature of both global governance studies and public administration scholarship. This special issue offers one vital step in advancing these types of studies by offering a 'public administration' approach. This entails that the study of international governmental organizations (IGOs) become somehow 'normalized', i.e. that a public administration turn comes to characterize IGO studies (Trondal 2007). Recent studies have suggested that international public administration (IPA) profoundly influence global governance (Biermann and Siebenhüner 2009), transform power distributions 
across levels of government (Egeberg and Trondal 2009), and change the conduct of domestic public sector governance (Keohane et al. 2009). Moreover, IPAs are called upon to cope with ever more wicked and unruly public problems. Turbulence in world politics is partly caused by turbulent political-administrative systems, partly by turbulent environments, and partly by how organizations and their environments poorly match - thus creating turbulence of scale. Together these challenges produce complexity, uncertainty, and time constraints for decisionmakers. Turbulence of these kinds reveals the fragility of existing institutions and serves as testbeds for the sustainability of existing governance arrangements. IPAs may be seen as one coping mechanism in an ever more turbulent global scene (Ansell et al. 2016).

Yet, public administration scholarship has largely deserted the comparative study of IPAs, including its multilevel character (Benz et al. 2016 <THIS ISSUE: PUBLISHER TO ADD /UPDATE DETAILS AT PROOF>). In this light, the current special issue is particularly welcomed. Moreover, this lacuna reflects generic gulfs between most social science sub-disciplines. For instance, despite vast scholarship on both (public sector) governance and organization theory, respectively, these strands of research have been in mutual disregard (e.g. Kettl 2002; Olsen 2010). Moreover, the empirical foci of several social science sub-disciplines often poorly intersect: For instance, whereas research on public sector organizations has largely focused on domestic ministerial departments and subordinate agencies (e.g. Verhoest et al. 2012), IGO scholarship has paid scant attention to their bureaucratic interior (e.g. Hawkins et al. 2006; Karns and Mingst 2004). Besides, European Union studies have primarily been preoccupied with 
studying the European Commission and subordinated regulatory agencies and largely neglected systematic comparative assessments (the $\mathrm{N}=1$ fallacy) (e.g. Bauer and Trondal 2015).

Modern governments daily formulate and execute policies with significant consequences for society. With the growing role of IPAs, one unresolved question is to what extent and under what conditions such institutions may formulate their own policies - and pursue a de facto autonomous regulatory agenda - and thereby transcend a mere intergovernmental secretarial role. The leeway of IGOs is arguably to a large extent supplied by the autonomy of its bureaucratic arm, that is, by the ability of IPAs to act relatively independently of decision premises that emanate from member-state governments (Barnett and Finnemore 2004; Biermann and Siebenhüner 2009, 2013; Cox and Jacobson 1973; Reinalda 2013; Trondal 2013). This special issue illuminates that IPAs are indeed rule-makers and sometimes even ruleimplementers. It is thus essential to know how autonomous IPAs are and how it can be explained. Scholars of various disciplines have started to explore the conditions under which IPAs are 'truly' independent of member-state governments, yet, the findings remain inconclusive (e.g., Beyers 2010; Checkel 2007; Moravcsik 1999). IPAs are seen as rifted between member-state dominance, the concern for the collective good, administrative 'siloization' and portfolio concerns, as well as transnational regulatory institutions driven by epistemic communities of experts (Trondal et al. 2015). As a consequence, academics, politicians and IPA officials have different views on the independent role of IPAs. This special issue indeed aims to connect some of the dots by offering new empirical findings. 


\section{THEORIZING IPAs: Beyond mapping}

One necessary factor in building common political order is the establishment of common institutions, including a permanent congress independent of national governments serving the common interest (Skowronek 1982). In an international context it necessitates the rise of separate international institutions that are able to act relatively independently. IPAs might indeed be such institutions. Whilst the empirical puzzle is to what extent IPAs enjoy de facto independence, the ensuing theoretical puzzle is to specify conditions thereof (Bauer and Ege 2016 <THIS ISSUE: PUBLISHER TO ADD /UPDATE DETAILS AT PROOF>). This special issue offers advances to both puzzles. It is shown that the task of IPAs has become increasingly that of active and independent policy-making institutions and less that of passive technical supply instruments for IGO plenary assemblies.

The classical study of IGOs did not permit an independent role for IPAs (Knill and Bauer 2016 <THIS ISSUE: PUBLISHER TO ADD /UPDATE DETAILS AT PROOF>). International-relations approaches viewed IGOs as epiphenomena to interstate relations. Regime literature similarly downplayed the organisational dimension of IGOs, and IGOs were largely seen as regime facilitators (Gehring 2003: 11). The seminal work of Cox and Jacobson (1973: 428) reflected this view by concluding that 'international organizations facilitate the orderly management of intergovernmental relations without significantly changing the structure of power that governs these relations...'. The 1960s and 1970s saw several studies of IGOs that treated them as hubs of international networks and regimes rather than as organizations and institutions in their own right (e.g. Nye 1975). The epistemic community literature focused on IGOs as facilitators of 
transnational epistemic communities (E. Haas 1990; P. Haas 1992). This literature made 'experts' and their 'ways of doing things' ever more paramount to studies of proposing, implementing and legitimizing public policy (Barnett and Finnemore 2004; Joerges 1999; Joerges et al. 1997: 7).

Concomitantly, beyond single-case studies of IPAs there were a surprising shortage of theoretically-informed comparative studies of their inner life and their wider role in global governance (Claude 1956). Consequently, 'to date, we do not really know how to conceptualize international organizations and how to deal with the organizational components...' of IPAs (Gehring 2003: 13). The research challenge targeted by this special issue is to bring IPAs back into the study of global governance and the study of public administration (Knill and Bauer 2016 <THIS ISSUE: PUBLISHER TO ADD /UPDATE DETAILS AT PROOF>; Eckhard and Ege $2016<$ THIS ISSUE: PUBLISHER TO ADD /UPDATE DETAILS AT PROOF>).

Assuming that IPAs 'matter' entails that we should take seriously how they are organized and how this may have consequences for decision-making processes and the subsequent pursuit of public policy making. In the classical study of decision-making processes in organizations, organizations were seen as permitting stable expectations providing general stimuli and attention directors to actors (Mintrom 2015). Yet, the way organizational structure shapes interaction, loyalty, cooperation, and information-processing are more adequately recognized in the organization theory literature than in most other social science literatures - for example the IGO literature (e.g. Cox and Jacobsen 1973), the governance literature (e.g. Levi-Faur 2012) as 
well as brother political science literatures (Olsen 2006). This special issue suggests that IPAs cannot be adequately understood without including organizational variables. Doing so implies bringing organizational structure and ways of organizing back into IGO studies. Organizational structure can be defined as role expectations with regard to who can and should do what, how and when. In this sense, the organization structure is a formalized, impersonal and normative structure that analytically separates structure from decision behaviour or process (Scott 1981). The organizational structure of IPAs consists both of the structure of the administration as well as how this structure is embedded in the wider IGO structure.

An organizational theory approach assumes that IPAs may possess 'own' organizational capacities that automize the behaviour of own administrative staff. This may happen through mechanisms such as control (behavioral adaptation through hierarchical control and supervision), discipline (behavioral adaptation through incentive systems), and/or socialization (behavioral internalization through established bureaucratic cultures) (Page 1992; Weber 1983). These mechanisms ensure that IPAs may perform their tasks relatively independently from outside pressure but within boundaries set by the legal authority and (political) leadership of which they serve (Weber 1924). Causal emphasis is put on the internal organizational structures of IPAs. This idea offers a picture of formal organizations as creators of 'organizational man' (Simon 1965) and as a stabilizing element in politics more broadly (Olsen 2010). IPAs may thus develop their own nuts and bolts quite independently of society, and concomitantly that international civil servants may act upon roles that are shaped by the IPA in which they are embedded. 
How can we adequately and accurately capture autonomy? Auto nomos refers to the Ancient Greek city-state - implying some kind of self-governing (Olsen 2009: 441). Contemporary understanding of this concept, however, varies and has been hotly debated. A working definition applied has been that 'autonomy is about discretion, or the extent to which [an organization] can decide itself about matters that it considers important' (Verhoest et al. 2010: 18-19). Whereas most literature on the independence of public sector organizations assesses autonomy by considering their de jure formal-legal design (e.g., Gilardi 2008; Huber and Shipan 2002), far less attention has been devoted to studying real-life autonomy of IPAs (Olsen 2009), for instance through how IPA staff themselves perceive their autonomy (Maggetti and Verhoest 2014: 245; Trondal 2010: 147). Bauer and Ege (2016 <THIS ISSUE: PUBLISHER TO ADD /UPDATE DETAILS AT PROOF $>$ ) capture autonomy by studying the capacity of the administration to develop autonomous preferences ('autonomy of will') and its ability to translate these preferences into action ('autonomy of action').

How then can we explain the autonomy of IPAs? This special issue suggests that organizational factors may be useful. One rationale for emphasising organizational factors is that 'the evidence remains still quite inconclusive about the effects of formal structural-organizational factors on the autonomy of agencies' and their employees' autonomy perceptions (Maggetti and Verhoest 2014: 247). Organizational factors include organization structure, organizational location, organizational demography and organizational culture (Egeberg et al. 2016). This special issue 
discusses two such variables: organizational structure and temporal sorting. This commentary would also add socialization dynamics to this discussion (see below).

Organizational structure: It is shown by this special issue that the role of IPAs reflects, broadly speaking, how they are organized. Similar organizational structures may for example account for why administrative styles are rather similar across IPAs (Knill et al. $2016<$ THIS ISSUE: PUBLISHER TO ADD /UPDATE DETAILS AT PROOF>). Organizational capacities may also account for the strong role of DG Budget in EU's new budgetary procedure (Goetz and Patz 2016 <THIS ISSUE: PUBLISHER TO ADD /UPDATE DETAILS AT PROOF>). Yet, proponents of an organizational theory approach (Egeberg et al. 2016) do not claim to provide a complete or comprehensive explanation of policy processes and policy contents. Rather, the argument is that organizational factors (independent variables) might intervene in actors' behavioural perceptions (dependent variable) and create a systematic bias, thus making some process characteristics and outputs more likely than others (Gulick 1937; March and Olsen 1984; Simon 1965). Organizations provide frames for storing experiences, cognitive maps categorizing complex information, procedures for reducing transaction costs, regulative norms that add cues for appropriate behaviour, and physical boundaries and temporal rhythms that guide actors' perceptions of relevance with respect to administrative behaviour. Organizations also discriminate between which conflicts should be attended to and which should be de-emphasized (Egeberg 2006). By organizing civil servants into permanent bureaucracies within IGOs, a system of 'rule followers and role players' is established relatively independently of the domestic branch of executive government (Barnett and Finnemore 2004; March and Olsen 1998: 952). 
One can assume, for instance, that organizational affiliations would matter for the autonomy of IPAs. One initial proposition is that the supply of independent administrative capacities in IPAs represents a primary organizational structure for IPA staff, whereas their secondary structures consist of part-time (such as transnational networks) or past organizational memberships (such as previous employments). IPAs serve as the primary organizational affiliation for international civil servants, rendering them particularly sensitive to the organizational signals and selections provided by this structure. The autonomy perceptions evoked by officials may thus be expected to be primarily directed towards those administrative units that are the primary supplier of relevant decision premises. Because IPA officials spend most of their time and energy in subunits of their primary organizations, they may be expected to chiefly attend to concerns of IPA subunits and less towards IGO as wholes (Ashforth and Johnson 2001: 36). Subsequently, IPA personnel are likely to orient their behaviour towards their present IPA units rather than to the concerns of member state governments. Administrative staff is thus expected to evoke 'inwardlooking' behavioural patterns geared towards their 'own' sub-units and task environments. We may expect that IPA officials evoke Weberian virtues of party-political neutrality, attaching identity towards their divisions and portfolios, and attending chiefly to administrative rules and proper procedures of their primary structure (Richards and Smith 2004).

A second assumption would be that the autonomy of IPAs is facilitated by how they are organizationally specialized. For example, administrative styles (see Knill et al. 2016 <THIS ISSUE: PUBLISHER TO ADD /UPDATE DETAILS AT PROOF>) may vary systematically between 
organizational sub-units - reflecting the departmentalization of IPAs. Organizations tend to accumulate conflicting organizational principles through horizontal and vertical specialization. When specializing formal organizations horizontally, one important principle (among several) is by major purpose served like research, health, food safety, etc. (Gulick 1937). This principle of specialization is recurrent inside IPAs. For example, the European Commission is a horizontally pillarized administration, specialized by purpose and with historically weak organizational capabilities for horizontal coordination at the top through administrative coordination and Presidential oversight (Dimitrakopoulos and Kassim 2005). However, recent administrative reforms and enhanced presidential ambitions to 'get the house in order' have improved such capacities somewhat (e.g. Kassim et al. 2013). Similarly, the WTO and OECD secretariats are also specialized administrations consisting of divisions or directorates responsible for different areas of cooperation, such as agriculture, environment, development, statistics, etc. This principle of organization tends to activate administrative styles among incumbents following sectoral cleavages. For example, coordination and contact patterns tend to be channeled within sectoral portfolios rather than between them. Arguably, organization by 'major purpose served' is likely to bias decision-making dynamics inwards toward the bureaucratic organization where preferences, contact patterns, roles, and loyalties are directed toward sectoral portfolios, divisions, and units. This mode of horizontal specialization results in less than adequate horizontal coordination across departmental units and better coordination within units (Ansell 2004: 237). The horizontal specialization of IPAs by major purpose is thus conducive to their autonomization. 
Temporal sorting: One often forgotten organizational variable in organization studies - as well as in the study of IPAs - is the temporal variable. This issue brings this variable back in (Goetz and Patz 2016 <THIS ISSUE: PUBLISHER TO ADD /UPDATE DETAILS AT PROOF>). As amplified by the garbage can approach, behavior and change in organizations have a temporal dimension (Cohen et al. 1976). As with the garbage can theory of organizations or the multiple streams approach to public policy, temporal complexity calls attention to the dynamic and sometimes paradoxical interaction of problems and solutions. The clash of time scales generates temporal complexity. A solution may lead a problem to change, cause new problems, or simply have trouble keeping up with the changing nature of problems. Temporal complexity should thus be one essential ingredient in our assessment of IPAs. For instance, polyrhythmic IPAs with several tempi would for example be considered more turbulent than IPAs geared towards only one tempo. Several rhythmic patterns may also concurrently co-exist in a mutually competing - yet compatible - whole. When several rhythmic patterns are layered like this, the resulting temporal system inside IPAs may become complex and challenging, but at the same time unlocking possibilities for innovation and change that are embedded in each pattern. Temporal complexity should thus be one essential ingredient in our assessment of IPAs.

We may also consider that certain temporal patterns within organizations match more easily with certain temporal patterns in the environments. For example, poly-rhythmic IPAs may relatively easily adapt to multiple and shifting rhythms in member-states. Mono-rhythmic IPAs, by contrast, would face relatively more uncertainty and risk if faced with multi-rhythmic member-states. Moreover, unsettled and weakly institutionalized IPAs with high temporal 
complexity might arguably adapt more easily to turbulent environments with high temporal complexity than settled and strongly institutionalized IPAs with low temporal complexity.

A second temporal variable is tempo, or speed. One might assume that with increased speed comes a tendency for repetition. During turbulent times when the tempo in IPAs increases, established governance practices might be subject to test. So, turbulence is likely to be inversely correlated with speed. High-speed governance processes are thus likely to experience a tendency to repeat past successes, or what is perceived as past successes (March 2010: 16). By repeating this way, IPAs may be victims of trained incapacity to improvise - merely due to high speed of conduct. Taking the example of jazz as a temporally sorted activity, jazz musicians may play very fast tunes, with the likely consequence of repetition of patterns just to keep the performance going' (Weick 1998: 553). Slow moving jazz, by contrast, would enable musicians' larger leeway for embellishment of items. Thus, up-tempo decision-making within IPAs may reduce the likelihood of exploration or innovation. But it may also speak to the need for an enhanced diversity of governance repertoires.

Socialization dynamics: Supplementing the role of organizational structures and temporal sorting, governing IPAs may also be subject to socialization effects. A vast literature reveals that the impact of pre-socialization of actors is modified by organizational re-socialization (e.g. Checkel 2007). Arguably, IPAs with a high socialization potential would more effectively automize its staff compared to IPAs with weaker socialization potential. Officials entering IPAs for the first time are subject to an organizational 'exposure effect' (Johnston 2005: 1039) that 
may contribute to such re-socialization. Socialization is a dynamic process whereby staff are induced into the norms and rules of a given community. By this process, individuals may come to gradually internalize some shared norms and rules of the community (Checkel 2007). Socialization processes are conducive to 'autonomization' of the socialized, because the one socializing may educate, indoctrinate, teach, or diffuse his or her norms and ideas to the one being socialized. The socialization argument also claims that behavioral autonomy is conditioned by enduring experiences with institutions, accompanying perceptions of appropriate behavior (Herrmann and Brewer 2004: 14). The potential for socialization to occur is assumed positively related to the duration and the intensity of interaction amongst the organizational members. Chief to the neo-functionalist approach, the potential for resocialization to occur ('shift of loyalty toward a new center') is assumed positively associated with the duration and the intensity of interaction among actors (Haas 1958: 16). Intensive ingroup interaction is assumed conducive to the emergence of relative stabile social, normative, and strategic networks that provide autonomous impact on the participants' perceptions of strategic and appropriate behavior (Atkinson and Coleman 1992: 161; Hay and Richards 2000). In sum, the length of stay in IPAs - or the individual seniority of incumbents - may foster socialization toward a supranational behavioral pattern. Concomitantly, behavioral and role autonomy is nurtured by the sheer quantity and quality of actor-interaction inside IPAs.

\section{LOOKING AHEAD}

There has been a lack of three kinds of IPA studies which this issue responds to: 
(i) Systematic comparative studies of IPAs by offering large- $\mathrm{N}$ data across cases (e.g. Barnett and Finnemore 2004);

(ii) Studies that takes organization seriously analyzing how the organisational architectures of IPAs may bias their everyday governance processes and subsequently the pursuit of public policy making (e.g. Trondal et al. 2010);

(iii) Studies that examines the varied consequences of the autonomization of IPAs, notably for member-state public sector governance (e.g. Bach et al. 2015) as well as for transnational regulatory regimes (e.g. Abbott et al. 2016).

Departing from the latter challenge, one promising research avenue is what kind of consequences that may emanate from the autonomization of IPAs. Studies of the European Commission suggest that capacity-building inside IPAs enables them to build ever-closer administrative networks with other IPAs and to pool administrative resources among these into some kind of common administrative capacity. IPAs may, for instance, capture agendas of other actors - such as member-state government institutions. This may fuel the emergence of multilevel administrative structures which facilitate policy coordination across levels of authority (Benz et al. 2016 <THIS ISSUE: PUBLISHER TO ADD /UPDATE DETAILS AT PROOF>). Studies suggest for instance that the rise of independent administrative capacities around the European Commission increase its ability to co-opt administrative sub-centers by stealth notably European Union agencies and domestic agencies. This enhanced ability to co-opt or capture, however, probably also reaches towards agencies within IGOs such as the WTO and the OECD - thus integrating and pooling global administrative resources. Moreover, studies suggest 
that compatible organizational structures among IPAs increase the likelihood of mutual integration among them. This is reflected in the development of direct links between Commission DGs and 'their' partner EU agencies (Egeberg et al. 2015) and between Commission DGs and domestic agencies and their agency networks (Egeberg et al. 2016). Egeberg and Trondal (2009) show for instance that the Commission takes active part in the daily practicing of EU legislation within domestic agencies, and thus that Commission DGs in practice partly co-opt domestic administrative resources. This example shows that the supply of administrative capacities inside IPAs may have profound consequences for emergence of integrated global governance infrastructure beyond direct member-state control. This special issue contributes both to empirical examination of such infrastructures and inspires future research of these.

Biographical notes: Jarle Trondal is Professor of Public Administration at the University of Agder, Department of Political Science and Management, and Professor of European Studies at the University of Oslo, ARENA Centre for European Studies.

Addresses for correspondence: Jarle Trondal, University of Agder, Post Box 422, 4604 Kristiansand, Norway. Email: Jarle.trondal@uia.no

\section{ACKNOWLEDGEMENTS}

This contribution is financially supported by the Norwegian Research Council ('EURODIV: Integration and division: Towards a segmented Europe') and the University of Agder ('COMPOL: 
The rise of common political order'). The author acknowledges valuable comments from Michael W. Bauer, Stefan Gänzle, Johan P. Olsen, and Jeremy Richardson.

\section{REFERENCES}

Abbott, K.W., J.F. Green and R.O Keohane (2016) 'Organizational ecology and institutional change in global governance', International Organization, DOI: 10.1017/S0020818315000338 Ansell, C.K. (2004) 'Territoriality, authority, and democracy', in C.K. Ansell and G. Di Palma (eds.) Restructuring Territoriality. Cambridge: Cambridge University Press.

Ansell, C.K., J. Trondal and M. Øgård (eds.) (2016) Governance in Turbulent Times. Oxford: Oxford University Press (forthcoming).

Ashford, B.E. and S.A. Johnson (2001) 'Which hat to wear? The relative salience of multiple identities in organizational contexts', in M.A. Hogg and D.J. Terry (eds.) Social Identity Processes in Organizational Contexts. Ann Arbor: Psychology Press.

Atkinson, M.M. and W.D. Coleman (1992) 'Policy networks, policy communities and the problems of governance', Governance 5(2): 154-80.

Bach, T., E. Ruffing and K. Yesilkagit (2015) 'The differential empowering effects of Europeanization on the autonomy of national agencies', Governance 28(3): 285-304.

Barnett, M., and M. Finnemore (2004) Rules for the World. Ithaca, NY: Cornell University Press.

Bauer, M.W. and Ege, J. 2016 <THIS ISSUE: PUBLISHER TO ADD /UPDATE DETAILS AT PROOF> Bauer, M.W., and Trondal, J. (2015) The Palgrave Handbook of the European Administrative System. Houndmills: Palgrave Macmillan. 
Benz, A., Corcaci, A. and Dose J. (2016) <THIS ISSUE: PUBLISHER TO ADD /UPDATE DETAILS AT PROOF>

Beyers, J. (2010) 'Conceptual and methodological challenges in the study of European socialization', Journal of European Public Policy 17(6): 909-20.

Biermann, F. and B. Siebenhüner (eds.) (2009) Managers of Global Change. Cambridge, MA: The MIT Press.

Bierman, F. and B. Siebenhuner (2013) 'Problem solving by international bureaucracies: the influence of international secretariats on world politics', in B. Reinalds (ed.) Routledge Handbook of International Organization. London: Routledge.

Checkel, J.T. (ed.) (2007) International Institutions and Socialization in Europe. Cambridge: Cambridge University Press.

Claude, I.L. Jr. (1956) Swords into Plowshares. New York: Random House.

Cohen, M.D., J.G. March and J.P. Olsen (1976) ‘People, problems, solutions and the ambiguity of relevance', in J.G. March and J.P. Olsen (eds.) Ambiguity and Choice. Bergen: Universitetsforlaget.

Cox, R.W., and H.K. Jacobson (1973). The Anatomy of Influence. New Haven, CT: Yale University Press.

Dimitrakopoulos, D.G. and H. Kassim (2005) 'The European Commission and the debate on the future of Europe', paper presented at the CONNEX workshop, 27-28 May, Oslo.

Eckhard S. and Ege, J. 2016 <THIS ISSUE: PUBLISHER TO ADD /UPDATE DETAILS AT PROOF> 
Egeberg, M. (ed.) (2006) Multilevel Union Administration. Basingstoke: Palgrave.

Egeberg, J., Å. Gornitzka and J. Trondal (2016) 'Organization theory', in C. Ansell and J. Torfing (eds.) Handbook on Theories of Governance. Cheltenham: Edward Elgar.

Egeberg, M. and J. Trondal (2009) 'National agencies in the European administrative space: Government driven, Commission driven, or networked?', Public Administration 87(): 779-790.

Egeberg, M., J. Trondal and N.M. Vestlund (2015) 'The quest for order: unravelling the relationship between the European Commission and European Union agencies', Journal of European Public Policy 22(5): 609-629.

Gehring, T. (2003) 'International institutions as decision-making systems. Lessons from the European Union', paper presented at the 8th Biennial International Conference of the European Studies Association, Nashville, TN.

Gilardi, F. (2008) Delegation in the Regulatory State. Cheltenham: Edward Elgar.

Goetz, K. and Patz, R. 2016 <THIS ISSUE: PUBLISHER TO ADD /UPDATE DETAILS AT PROOF> Gulick, L. (1937) 'Theory of organizations. With special references to government in the United States', in L. Gulick and D. Urwick (eds.) Papers on the Science of Administration. New York: Columbia University.

Haas, E. (1958) The Uniting of Europe. Stanford: Stanford University Press. 
Haas, E. (1990) When Knowledge Is Power. Three Models of Change in International Organizations. Berkeley: University of California Press.

Haas, P. (1992) 'Epistemic communities and international policy coordination', International Organization 46(1): 1-35.

Hay, C. and D. Richards (2000) 'The tangled webs of Westminister and Whitehall: The discourse, strategy and practice of networking within the British core executive', Public Administration 78(1): 1-28.

Hawkins, D.G., D.A. Lake, D.L. Nielson and M.J. Tierney (2006) Delegation and Agency in International Organizations. Cambridge, UK: Cambridge University Press.

Herrmann, R. and M.B. Brewer (2004) 'Identities and institutions: Becoming European in the EU', in R.K. Herrmann, T. Risse and M.B. Brewer (eds.) Transnational Identities. Lanham: Rowman \& Littlefield Publishers.

Huber, J.D. and C.R. Shipan (2002) Deliberate Discretion? Cambridge: Cambridge University Press.

Joerges, C. (1999) 'bureaucratic nightmare, technocratic regime and the dream of god transnational governance', in C. Joerges and E. Vos (eds.) EU Committees: Social Regulation, Law and Politics. Oxford: Hart Publishing.

Joerges, C., K.-H. Ladeur and E. Vos (eds.) (1997) Integrating Scientific Expertise into Regulatory Decision-Making. Baden-Baden: Nomos. 
Johnston, A.I. (2005) 'Conclusions and extensions: Towards mid-range theorizing and beyond Europe', International Organization 59: 1013-1044.

Karns, M.P. and K.A. Mingst (2004) International Organizations. London: Lynne Rienner Publishers.

Kassim, H., J. Peterson, M.W. Bauer, S. Connolly, R. Dehousse, L. Hooghe and A. Thompson (2013) The European Commission of the Twenty-First Century. Oxford: Oxford University Press.

Keohane, R.O., S. Macedo and A. Moravcsik (2009) 'Democracy-enhancing multilateralism', International Organization 63: 1-31.

Knill, C. and M.W. Bauer (2016) <THIS ISSUE: PUBLISHER TO ADD /UPDATE DETAILS AT PROOF> Knill C. et al 2016 <THIS ISSUE: PUBLISHER TO ADD /UPDATE DETAILS AT PROOF> Levi-Faur, D. (ed.) (2012) The Oxford Handbook of Governance. Oxford: Oxford University Press. Maggetti, M. and K. Verhoest (2014) 'Unexplored aspects of bureaucratic autonomy: a state of the field and ways forward', International Review of Administrative Sciences 80(2): 239-56.

March, J.G. (2010) The Ambiguities of Experience. Ithaca: Cornell University Press. March, J.G. and J.P. Olsen (1984) 'The new institutionalism: organizational factors in political life', American Political Science Review 78: 734-49.

March, J.G. and J.P. Olsen (1998) 'The institutional dynamics of international political orders', International Organization 52(4): 943-969. 
Mintrom, M. (2015) 'Herbert A. Simon, administrative behavior: A study of decision-making processes in administrative organization', in S.J. Balla, M. Lodge and E.C. Page (eds.) The Oxford Handbook of Classics in Public Policy and Administration. Oxford: Oxford University Press.

Moravcsik, A. (1999) 'A new statecraft? Supranational entrepreneurs and international

cooperation', International Organization 53(2): 267-306.

Nye, R.O. (1975) 'International organization and the crisis of interdependence', International Organization 29(2): 357-365.

Olsen, J.P. (2006) 'Maybe it is time to rediscover bureacuracy', Journal of Public Administration Research and Theory 16(1): 1-24.

Olsen, J.P. (2009) 'Democratic government, institutional autonomy and the dynamics of change', West European Politics 32(3): 439-465.

Olsen JP (2010) Governing through Institutional Building. Oxford: Oxford University Press.

Page, E.C. (1992) Political Authority and Bureaucratic Power. New York: Harvester Wheatsheaf. Reinalda, B. (2013) 'International organization as a field of research since 1910', in B. Reinalds (ed.) Routledge Handbook of International Organization. London: Routledge.

Richards, D. and M.J. Smith (2004) 'Interpreting the world of political elites', Public Administration 82(4): 777-800.

Scott, W.R. (1981) Organizations. Rational, Natural, and Open Systems. Englewood Cliffs, NJ: Prentice Hall.

Simon, H. A. (1965) Administrative Behavior. New York: The Free Press. 
Skowronek, S. (1982) Building a New American State. Cambridge: Cambridge University Press.

Trondal, J. (2007) 'The public administration turn in integration research', Journal of European Public Policy 14(6): 960-972.

Trondal, J. (2010) An Emergent European Executive Order. Oxford: Oxford University

Press.

Trondal, J. (2013) 'International bureaucracy. Organizational structure and behavioural implications', in B. Reinalda (ed.) Routledge Handbook of International Organization. London: Routledge.

Trondal, J., M. Marcussen. T. Larsson and F. Veggeland (2010) Unpacking International Organizations. Manchester: Manchester University Press.

Trondal, J., Z. Murdoch and B. Geys (2015) 'Representative bureaucracy and the role of expertise in politics', Politics and Governance 3(1): 26-36.

Verhoest, K., P.G. Roness, B. Verschuere, K. Rubecksen, and M. MacCarthaigh (2010) Autonomy and Control of State Agencies. Houndmills: Palgrave Macmillan.

Verhoest, K., S. Van Thiel, G. Bouckaert and P. Lægreid (eds.) (2012) Government Agencies. Hounmills: Palgrave Macmillan.

Weber, M. (1924) 'Legitimate authority and bureaucracy', in D.S. Pugh (ed.) (1990) Organization Theory. London: Penguin Books.

Weber, M. (1983) On Capitalism, Bureaucracy and Religion. Glasgow: Harper Collins Publishers. 
Weick, K.E. (1998) 'Improvisation as a mindset for organizational analysis', Organization Science 9(5): 543-555. 